\title{
High-Pressure Densities and Derived Thermodynamic Properties of Imidazolium-Based Ionic Liquids
}

\author{
Ramesh L. Gardas, ${ }^{\dagger}$ Mara G. Freire, ${ }^{\dagger}$ Pedro J. Carvalho, ${ }^{\dagger}$ Isabel M. Marrucho, ${ }^{\dagger}$ Isabel M. A. Fonseca,,$\dagger$ \\ Abel G. M. Ferreira, ${ }^{*}$ and João A. P. Coutinho*,
}

CICECO, Departamento de Química, Universidade de Aveiro, 3810-193 Aveiro, Portugal, and Departamento de Engenharia Química, Faculdade de Ciências a Tecnologia, Universidade de Coimbra, Polo II, Pinhal de Marrocos, 3030-290 Coimbra, Portugal

\begin{abstract}
This work addresses the experimental measurements of the pressure $(0.10<p / \mathrm{MPa}<10.0)$ and temperature $(293.15<T / \mathrm{K}<393.15)$ dependence of the density and derived thermodynamic properties, such as the isothermal compressibility, the isobaric expansivity, the thermal pressure coefficient, and the pressure dependence of the heat capacity of several imidazolium-based ionic liquids (ILs), namely, 1-butyl-3-methylimidazolium tetrafluoroborate, $[\mathrm{bmim}]\left[\mathrm{BF}_{4}\right] ; 3$-methyl-1-octylimidazolium tetrafluoroborate, [omim] $\left[\mathrm{BF}_{4}\right]$; 1-hexyl-3-methylimidazolium hexafluorophosphate, $[\mathrm{hmim}]\left[\mathrm{PF}_{6}\right]$; 3-methyl-1-octylimidazolium hexafluorophosphate, [omim] $\left.\mathrm{PF}_{6}\right]$; 1-butyl2,3-dimethylimidazolium hexafluorophosphate, $[\mathrm{bmmim}]\left[\mathrm{PF}_{6}\right]$; and 1-butyl-3-methylimidazolium trifluoromethansulfonate, $[\mathrm{bmim}]\left[\mathrm{CF}_{3} \mathrm{SO}_{3}\right]$. These ILs were chosen to provide an understanding of the influence of the cation alkyl chain length, the number of cation substitutions, and the anion influence on the properties under study. The influence of water content in the density was also studied for the most hydrophobic IL used, [omim]$\left[\mathrm{PF}_{6}\right]$. A simple ideal-volume model was employed for the prediction of the imidazolium molar volumes at ambient conditions, which proved to agree well with the experimental results.
\end{abstract}

\section{Introduction}

Ionic liquids (ILs) have been the object of increasing attention due to their unique physicochemical properties such as high thermal stability, large liquidus range, high ionic conductivity, high solvating capacity, negligible vapor pressure, and nonflammability that make them ideal solvents for green chemistry and clean synthesis. ${ }^{1-7}$ ILs also present significant cost reduction and environmental benefits because they can be used in many extraction and cyclic processes without losses, in contrast with the volatile organic compounds used nowadays. ${ }^{1,8-10}$ Furthermore, the promising physical and chemical properties of ILs allow their use as electrolytes for diverse technologies (e.g., in lithium secondary batteries, photoelectrical and fuel cells, electric double-layer capacitors, and other electrochemical devices). Regarding electrochemical processes, ILs seem to be convenient solvents since their ionic structures should afford good conductivity without the addition of a supporting electrolyte.

The design of industrial processes and new products based on ILs are only possible when their thermophysical properties including viscosity, density, and interfacial tension are adequately known. Unfortunately, the thermophysical property characterization of ILs is limited, and it is necessary to accumulate a sufficiently large data bank on the fundamental physical and chemical properties, not only for process and product design but also for the development of adequate correlations for these properties.

ILs are typically a combination of bulky organic cations and soft anions. Since a large number of cationic and anionic

\footnotetext{
* Corresponding author. E-mail: jcoutinho@dq.ua.pt.

Universidade de Aveiro.

$\doteqdot$ Universidade de Coimbra.
}

structures combinations are possible, their physicochemical properties can be easily tuned by changing the structure of the component ions. Thus, a goal of the present study is to present reliable density data for a series of six ILs and their temperature and pressure dependence. As it is impossible to measure all possible combinations of anions and cations, it is necessary to make measurements on selected systems to provide results that can be used to develop correlations and to test predictive methods.

The objective of this work is to investigate the relationship between ionic structures and their density in order to establish principles for the molecular design of ILs. For that purpose, the [bmim] cation was studied in combination with two anions, $\left[\mathrm{CF}_{3} \mathrm{SO}_{3}\right]$ and $\left[\mathrm{BF}_{4}\right]$, and the [omim] cation was studied in combination with the $\left[\mathrm{BF}_{4}\right]$ and $\left[\mathrm{PF}_{6}\right]$ anions to provide conclusions about the anion effect. On other hand, the $\left[\mathrm{PF}_{6}\right]$ anion was combined with three different cations ([bmmim], [hmim] and [omim]) to study the effect of alkyl chain length and the number of substituents on the imidazolium ring on the density and derived properties.

The results of the current study indicate that the density of the imidazolium-based ILs can be manipulated by judicious selection of the cation and anion. A regular increase in the molar volume with the addition of $-\mathrm{CH}_{2}$ groups to the cation alkyl chain length was observed. The molar volume is also proportional to the anion effective size, and a simple ideal-volume model is shown to provide a good description of the imidazolium molar volumes at ambient conditions.

It was already shown that the presence of water in the IL has a considerable effect in the physical properties of ILs. ${ }^{11-12}$ For that reason, the study of the density of $\left[\mathrm{omim}^{2}\left[\mathrm{PF}_{6}\right]\right.$ saturated with water at $293.15 \mathrm{~K}$ was also included in order to evaluate the extension of the influence of the water content in the density 
and related derived properties for the most hydrophobic of the ILs studied.

The liquid densities were correlated with the Tait equation; ${ }^{13}$ other thermodynamic properties such as the isothermal compressibility, the isobaric expansivity, the thermal pressure coefficient, and the pressure dependence of the heat capacity were calculated and shown in some examples. The results show that the two-parameter Tait equation correlates well the pure ILs studied with deviations from experimental data less than $0.02 \%$. For the water-saturated IL isothermal densities, the Tait equation does not provide such a good description, presenting a maximum deviation from the experimental data of $1.2 \%$.

\section{Experimental Section}

Materials. Experimental densities were measured for six imidazolium-based ILs, namely, $[\mathrm{bmim}]\left[\mathrm{BF}_{4}\right]$, [omim] $\left[\mathrm{BF}_{4}\right]$, $[\mathrm{hmim}]\left[\mathrm{PF}_{6}\right]$, [omimPF 6 , [bmmim] $\left[\mathrm{PF}_{6}\right]$, and $[\mathrm{bmim}]\left[\mathrm{CF}_{3} \mathrm{SO}_{3}\right]$. [bmim $]\left[\mathrm{BF}_{4}\right]$ was acquired at Solvent Innovation with a mass fraction purity $>98 \%$ and a mole fraction of chloride ion of $100 \times 10^{-6}$. [omim] $\left[\mathrm{BF}_{4}\right]$ and $[\mathrm{bmim}]\left[\mathrm{CF}_{3} \mathrm{SO}_{3}\right]$ were acquired at IoLiTec with mass fraction purities $>99 \%$. The bromide impurity mole fraction in the $[\mathrm{omim}]\left[\mathrm{BF}_{4}\right]$ is $64 \times 10^{-6}$, and the $[\mathrm{bmim}]\left[\mathrm{CF}_{3} \mathrm{SO}_{3}\right]$ is halogen-free since it was produced directly from butylimidazole and methyltriflate. [hmim] $\left[\mathrm{PF}_{6}\right]$ was acquired at Merck with a mass fraction purity $\geq 99 \%$ and a mole fraction of chloride ion $\leq\left(100 \times 10^{-6}\right)$. [omim] $\left[\mathrm{PF}_{6}\right]$ and $[\mathrm{bmmim}]\left[\mathrm{PF}_{6}\right]$ were acquired at Solchemar with mass fraction purities $>99 \%$. The chloride mole fraction content in both ILs is $<\left(80 \times 10^{-6}\right)$.

In order to reduce the water content and volatile compounds to negligible values, vacuum $(0.1 \mathrm{~Pa})$ at moderate temperature $(353 \mathrm{~K})$ for at least $48 \mathrm{~h}$ was applied to all the ILs samples prior to their use. After this procedure, the water content in the ILs was determined with a Metrohm 831 Karl Fischer coulometer indicating very low levels of water mass fraction content, as $(485,371,181,311,87$ and 18$) \times 10^{-6}$ for $[\mathrm{bmim}]\left[\mathrm{BF}_{4}\right]$, [omim] $\left[\mathrm{BF}_{4}\right],[\mathrm{bmim}]\left[\mathrm{CF}_{3} \mathrm{SO}_{3}\right],[\mathrm{bmmim}]\left[\mathrm{PF}_{6}\right],[\mathrm{hmim}]\left[\mathrm{PF}_{6}\right]$, and $\left[\mathrm{omim}^{\mathrm{om}}\left[\mathrm{PF}_{6}\right]\right.$, respectively.

The influence of water content in density was studied for [omim] $\left[\mathrm{PF}_{6}\right]$. For that purpose, this compound was saturated with ultrapure water, maintaining the two phases in equilibrium, at $293.15 \mathrm{~K}$ for at least $48 \mathrm{~h}$, which was previously found to be the necessary time to achieve equilibrium. The water mass fraction content in the saturated $[\mathrm{omim}]\left[\mathrm{PF}_{6}\right]$ was $(11905 \pm$ $98) \times 10^{-6}$. The water used was double-distilled, passed by a reverse osmosis system, and further treated with a Milli-Q plus 185 water purification apparatus. It has a resistivity of $18.2 \mathrm{M} \Omega$ • $\mathrm{cm}$, has a TOC smaller than $5 \mu \mathrm{g} \cdot \mathrm{L}^{-1}$, and is free of particles greater than $0.22 \mu \mathrm{m}$.

Apparatus and Procedure. Experimental densities were measured using an Anton Paar DMA 60 digital vibrating-tube densimeter, with a DMA 512P measuring cell in the temperature range (293.15 to 393.15) $\mathrm{K}$ and pressure range of (0.10 to 10.0) $\mathrm{MPa}$. The temperature in the vibrating-tube cell was measured with a platinum resistance probe that has a temperature uncertainty of $\pm 0.01 \mathrm{~K}$ coupled with a GW Instek Dual Display Digital Multimeter GDM-845. A Julabo P-5 thermostatic bath with silicone oil as circulating fluid was used in the thermostat circuit of the measuring cell, which was held constant to \pm 0.01 $\mathrm{K}$. The diameter of tube is $1 / 16$ in., and the buffer is more than $1 \mathrm{~m}$ in length, which guarantees the inexistence of diffusion of the hydraulic liquid in the liquid contained in the cell of densimeter.
The required pressure was generated and controlled with a pressure generator model 50-6-15, Mftd. from High Pressure Equipment Co., using acetone as the hydraulic fluid. Pressures were measured with a pressure transducer (Wika transmitter S-10, Mftd. from WIKA Alexander Wiegand $\mathrm{GmbH} \& \mathrm{Co}$.) with a maximum uncertainty of $\pm 0.025 \mathrm{MPa}$.

Water, $n$-perfluorohexane, and $n$-perfluorononane were used as reference fluids for the calibration of the vibrating-tube densimeter in order to guarantee an interpolation besides an extrapolation of the IL densities. ${ }^{14-16}$ The reference fluids density data were used to fit the calibration equation proposed by Niesen, ${ }^{17}$ which has a solid theoretical basis as discussed by Holcomb and Outcalt. ${ }^{18}$ It can be described as follows:

$\rho(T, p, \tau)=$

$$
A_{1}+A_{2} T+A_{3} p+\left[\frac{\tau^{2}(T, p)\left(A_{4}+A_{5} T+A_{6} T^{2}\right)}{\tau^{2}\left(T_{0}, p_{0}=0\right)}\right]
$$

where $\rho(T, p)$ and $\tau(T, p)$ are the density and the vibration period, respectively, which are both functions of the temperature $T$ and the pressure $p$. The vibration period $\tau\left(T_{0}, p_{0}\right)$ is a measure of the reference temperature $T_{0}$ and vacuum. In this work, $T_{0}=303.15 \mathrm{~K}$ and the measured period at $p=0$ is $\tau\left(T_{0}, p_{0}\right)=$ $0.388074 \mu \mathrm{s}$.

For water, the density data from Saul and Wagner ${ }^{14}$ and those taken from National Institute of Science and Technology $(\mathrm{NIST})^{15}$ in the temperature range of (293.15 to 393.15) K and pressures from (0.1 to 35) $\mathrm{MPa}$ were used, while for the $n$-perfluorohexane and n-perfluorononane reference fluids, density data were taken from Piñeiro et al. ${ }^{16}$ in the same pressure and temperature range of this work. The standard deviation of the fitting $\sigma$ is defined as

$$
\sigma=\left[\frac{\sum_{i=1}^{N_{\mathrm{p}}}\left(\rho_{\text {cal }}-\rho_{\text {exp }}\right)_{i}^{2}}{N_{\mathrm{p}}-k}\right]^{1 / 2}
$$

where $\rho_{\text {cal }}$ and $\rho_{\text {exp }}$ are respectively the density data from eq 1 and the experimental data for the measurement $i, N_{\mathrm{p}}$ represents the number of points used $\left(N_{\mathrm{p}}=174\right)$, and $k$ is the number of adjusted parameters $(k=6)$ providing a standard deviation of the fitting of the order of $\pm 1 \mathrm{~kg} \cdot \mathrm{m}^{-3}$. The percentage average absolute deviation, $\operatorname{AAD}(\%)$, from the experimental data to the fitting is defined according to

$$
\operatorname{AAD}(\%)=\frac{\sum_{i=1}^{N_{\mathrm{p}}}\left|\left(\rho_{\text {cal }}-\rho_{\text {exp }}\right) / \rho_{\text {exp }}\right|_{i}}{N_{\mathrm{p}}} \times 100
$$

providing an average value of $\mathrm{AAD}(\%)$ of $0.002 \%$ for all the ILs studied.

The influence of the viscosity on the densities was evaluated. In order to check the effect of viscosity in the density, a viscosity correction for compounds with viscosities $<100 \mathrm{mPa} \cdot \mathrm{s}$ was applied with the equation proposed for the density uncertainty of an Anton Paar DMA 512 densimeter. ${ }^{19}$ For compounds with viscosities higher than $400 \mathrm{mPa} \cdot \mathrm{s}$, the correction factor becomes constant ${ }^{20}$ and equal to $0.5 \mathrm{~kg} \cdot \mathrm{m}^{-3}$. Between (100 and 400) $\mathrm{mPa} \cdot$ $\mathrm{s}$, the viscosities correction follows an intermediate behavior. Considering, for example, the available viscosity data for $[\mathrm{bmim}]\left[\mathrm{BF}_{4}\right]^{21,22}$ and for $[\mathrm{bmim}]\left[\mathrm{CF}_{3} \mathrm{SO}_{3}\right]^{21,22}$ at atmospheric pressure and between (298.15 to 343.15$) \mathrm{K}$ where the viscosity 
Table 1. Experimental Density $(\rho)$ Data for $[\mathrm{bmim}]\left[\mathrm{BF}_{4}\right]$, [omim] $\left[\mathrm{BF}_{4}\right]$, and $[\mathrm{bmim}]\left[\mathrm{CF}_{3} \mathrm{SO}_{3}\right]$

\begin{tabular}{|c|c|c|c|c|c|c|c|c|c|c|c|}
\hline \multirow{2}{*}{$\frac{p}{\mathrm{MPa}}$} & \multicolumn{11}{|c|}{$\rho /\left(\mathrm{kg} \cdot \mathrm{m}^{-3}\right)$ at $T / \mathrm{K}$} \\
\hline & 293.15 & 303.15 & 313.15 & 323.15 & 333.15 & 343.15 & 353.15 & 363.15 & 373.15 & 383.15 & 393.15 \\
\hline \multicolumn{12}{|c|}{$[\mathrm{bmim}]\left[\mathrm{BF}_{4}\right]$} \\
\hline 0.10 & 1206.9 & 1198.6 & 1190.8 & 1183.0 & 1175.8 & 1168.4 & 1161.3 & 1154.7 & 1148.2 & 1142.0 & 1136.1 \\
\hline 1.00 & 1207.3 & 1199.1 & 1191.3 & 1183.5 & 1176.3 & 1168.9 & 1161.8 & 1155.3 & 1148.8 & 1142.5 & 1136.7 \\
\hline 2.00 & 1207.7 & 1199.6 & 1191.8 & 1184.0 & 1176.9 & 1169.3 & 1162.4 & 1155.8 & 1149.3 & 1143.1 & 1137.3 \\
\hline 3.00 & 1208.2 & 1200.1 & 1192.2 & 1184.5 & 1177.4 & 1169.8 & 1163.0 & 1156.4 & 1149.9 & 1143.7 & 1137.9 \\
\hline 4.00 & 1208.7 & 1200.7 & 1192.7 & 1185.0 & 1177.9 & 1170.3 & 1163.5 & 1156.9 & 1150.4 & 1144.3 & 1138.4 \\
\hline 5.00 & 1209.1 & 1201.1 & 1193.2 & 1185.5 & 1178.4 & 1170.8 & 1164.1 & 1157.5 & 1151.0 & 1144.8 & 1139.0 \\
\hline 10.0 & 1211.3 & 1203.5 & 1195.5 & 1187.8 & 1181.0 & 1173.1 & 1166.6 & 1160.1 & 1153.6 & 1147.6 & 1141.9 \\
\hline \multicolumn{12}{|c|}{$[\mathrm{omim}]\left[\mathrm{BF}_{4}\right]$} \\
\hline 0.10 & 1108.7 & 1100.7 & 1092.9 & 1085.4 & 1078.2 & 1071.4 & 1064.7 & 1058.6 & 1052.4 & 1046.6 & 1040.9 \\
\hline 1.00 & 1109.1 & 1101.1 & 1093.4 & 1085.9 & 1078.7 & 1072.0 & 1065.2 & 1059.1 & 1053.0 & 1047.2 & 1041.5 \\
\hline 2.00 & 1109.6 & 1101.6 & 1093.9 & 1086.4 & 1079.3 & 1072.5 & 1065.8 & 1059.8 & 1053.7 & 1047.9 & 1042.1 \\
\hline 3.00 & 1110.0 & 1102.1 & 1094.4 & 1087.0 & 1079.8 & 1073.1 & 1066.4 & 1060.4 & 1054.3 & 1048.5 & 1042.8 \\
\hline 4.00 & 1110.5 & 1102.6 & 1094.9 & 1087.5 & 1080.3 & 1073.7 & 1067.0 & 1061.0 & 1054.9 & 1049.2 & 1043.4 \\
\hline 5.00 & 1110.9 & 1103.1 & 1095.4 & 1088.0 & 1080.9 & 1074.2 & 1067.6 & 1061.6 & 1055.5 & 1049.8 & 1044.1 \\
\hline 10.0 & 1113.1 & 1105.4 & 1097.9 & 1090.6 & 1083.5 & 1076.9 & 1070.3 & 1064.4 & 1058.5 & 1052.9 & 1047.2 \\
\hline \multicolumn{12}{|c|}{$[\mathrm{bmim}]\left[\mathrm{CF}_{3} \mathrm{SO}_{3}\right]$} \\
\hline 0.10 & 1306.1 & 1296.6 & 1287.6 & 1278.7 & 1270.5 & 1262.5 & 1254.0 & 1246.8 & 1239.6 & 1232.4 & 1225.3 \\
\hline 1.00 & 1306.6 & 1297.1 & 1288.1 & 1279.3 & 1271.1 & 1263.1 & 1254.7 & 1247.5 & 1240.3 & 1233.1 & 1226.1 \\
\hline 2.00 & 1307.1 & 1297.7 & 1288.7 & 1280.0 & 1271.7 & 1263.8 & 1255.3 & 1248.3 & 1241.1 & 1233.9 & 1226.8 \\
\hline 3.00 & 1307.7 & 1298.3 & 1289.3 & 1280.7 & 1272.4 & 1264.5 & 1256.0 & 1249.0 & 1241.8 & 1234.6 & 1227.6 \\
\hline 4.00 & 1308.2 & 1298.9 & 1289.9 & 1281.3 & 1273.1 & 1265.2 & 1256.7 & 1249.7 & 1242.5 & 1235.4 & 1228.4 \\
\hline 5.00 & 1308.8 & 1299.5 & 1290.5 & 1282.0 & 1273.8 & 1265.8 & 1257.4 & 1250.4 & 1243.2 & 1236.1 & 1229.1 \\
\hline 10.0 & 1311.5 & 1302.3 & 1293.3 & 1285.0 & 1276.9 & 1269.1 & 1260.7 & 1253.8 & 1246.6 & 1239.7 & 1232.7 \\
\hline
\end{tabular}

Table 2. Experimental Density ( $\rho)$ Data for $[\mathrm{bmmim}]\left[\mathrm{PF}_{6}\right]$, $[\mathrm{hmim}]\left[\mathrm{PF}_{6}\right]$, and Dry and Water-Saturated [omim] $\left[\mathrm{PF}_{6}\right]$

\begin{tabular}{|c|c|c|c|c|c|c|c|c|c|c|c|}
\hline \multirow{2}{*}{$\frac{p}{\mathrm{MPa}}$} & \multicolumn{11}{|c|}{$\rho /\left(\mathrm{kg} \cdot \mathrm{m}^{-3}\right)$ at $T / \mathrm{K}$} \\
\hline & 293.15 & 303.15 & 313.15 & 323.15 & 333.15 & 343.15 & 353.15 & 363.15 & 373.15 & 383.15 & 393.15 \\
\hline \multicolumn{12}{|c|}{$[\mathrm{bmmim}]\left[\mathrm{PF}_{6}\right]$} \\
\hline 0.10 & & & 1339.6 & 1330.9 & 1321.9 & 1313.5 & 1305.4 & 1297.6 & 1290.6 & 1283.4 & 1276.1 \\
\hline 1.00 & & & 1340.0 & 1331.4 & 1322.4 & 1314.1 & 1306.0 & 1298.2 & 1291.2 & 1284.0 & 1276.8 \\
\hline 2.00 & & & 1340.7 & 1331.9 & 1323.0 & 1314.6 & 1306.6 & 1298.8 & 1291.9 & 1284.7 & 1277.4 \\
\hline 3.00 & & & 1341.2 & 1332.5 & 1323.5 & 1315.2 & 1307.2 & 1299.4 & 1292.5 & 1285.3 & 1278.1 \\
\hline 4.00 & & & 1341.6 & 1333.1 & 1324.1 & 1315.8 & 1307.8 & 1300.1 & 1293.2 & 1286.0 & 1278.8 \\
\hline 5.00 & & & 1342.1 & 1333.6 & 1324.6 & 1316.3 & 1308.3 & 1300.7 & 1293.8 & 1286.6 & 1279.4 \\
\hline 10.0 & & & 1344.6 & 1336.2 & 1327.2 & 1319.1 & 1311.1 & 1303.6 & 1296.7 & 1289.7 & 1282.6 \\
\hline \multicolumn{12}{|c|}{$[\mathrm{hmim}]\left[\mathrm{PF}_{6}\right]$} \\
\hline 0.10 & 1299.8 & 1290.6 & 1281.5 & 1272.7 & 1264.2 & 1256.1 & 1248.0 & 1240.6 & 1233.4 & 1226.4 & 1219.4 \\
\hline 1.00 & 1300.3 & 1291.1 & 1282.0 & 1273.2 & 1264.8 & 1256.7 & 1248.6 & 1241.2 & 1234.1 & 1227.2 & 1220.1 \\
\hline 2.00 & 1300.8 & 1291.7 & 1282.6 & 1273.9 & 1265.4 & 1257.3 & 1249.2 & 1242.0 & 1234.9 & 1227.9 & 1220.9 \\
\hline 3.00 & 1301.4 & 1292.2 & 1283.1 & 1274.5 & 1266.0 & 1258.0 & 1249.9 & 1242.6 & 1235.6 & 1228.7 & 1221.7 \\
\hline 4.00 & 1301.9 & 1292.7 & 1283.7 & 1275.0 & 1266.6 & 1258.6 & 1250.5 & 1243.3 & 1236.3 & 1229.4 & 1222.5 \\
\hline 5.00 & 1302.4 & 1293.2 & 1284.3 & 1275.6 & 1267.3 & 1259.2 & 1251.2 & 1244.0 & 1237.0 & 1230.1 & 1223.3 \\
\hline 10.0 & 1304.9 & 1295.8 & 1287.0 & 1278.5 & 1270.3 & 1262.0 & 1254.2 & 1247.2 & 1240.3 & 1233.6 & 1227.0 \\
\hline \multicolumn{12}{|c|}{$[\mathrm{omim}]\left[\mathrm{PF}_{6}\right]$} \\
\hline 0.10 & 1242.4 & 1233.8 & 1225.3 & 1217.6 & 1209.1 & 1201.0 & 1193.6 & 1186.2 & 1179.2 & 1172.7 & 1166.0 \\
\hline 1.00 & 1242.9 & 1234.4 & 1225.9 & 1218.2 & 1209.7 & 1201.6 & 1194.3 & 1186.9 & 1179.9 & 1173.5 & 1166.8 \\
\hline 2.00 & 1243.5 & 1235.0 & 1226.5 & 1218.8 & 1210.3 & 1202.3 & 1195.0 & 1187.6 & 1180.6 & 1174.2 & 1167.5 \\
\hline 3.00 & 1244.1 & 1235.6 & 1227.1 & 1219.4 & 1211.0 & 1203.0 & 1195.7 & 1188.3 & 1181.3 & 1174.9 & 1168.3 \\
\hline 4.00 & 1244.6 & 1236.1 & 1227.7 & 1220.0 & 1211.6 & 1203.6 & 1196.3 & 1189.0 & 1182.0 & 1175.6 & 1169.1 \\
\hline 5.00 & 1245.1 & 1236.7 & 1228.3 & 1220.6 & 1212.2 & 1204.3 & 1197.1 & 1189.7 & 1182.7 & 1176.3 & 1169.8 \\
\hline 10.0 & 1247.8 & 1239.5 & 1231.1 & 1223.4 & 1215.1 & 1207.4 & 1200.3 & 1193.0 & 1186.1 & 1179.8 & 1173.5 \\
\hline \multicolumn{12}{|c|}{ [omim] $\left[\mathrm{PF}_{6}\right]$ Saturated with Water at $293.15 \mathrm{~K}$} \\
\hline 0.10 & 1237.2 & 1228.1 & 1219.9 & 1211.0 & 1202.6 & 1194.6 & 1186.89 & 1179.3 & 1172.6 & 1165.4 & \\
\hline 1.00 & 1237.7 & 1228.7 & 1220.5 & 1211.5 & 1203.1 & 1195.2 & 1187.53 & 1180.0 & 1173.3 & 1166.1 & \\
\hline 2.00 & 1238.3 & 1229.2 & 1221.1 & 1212.1 & 1203.8 & 1195.9 & 1188.22 & 1180.7 & 1174.0 & 1166.8 & \\
\hline 3.00 & 1238.8 & 1229.8 & 1221.7 & 1212.7 & 1204.4 & 1196.6 & 1188.91 & 1181.4 & 1174.7 & 1167.5 & \\
\hline 4.00 & 1239.3 & 1230.4 & 1222.2 & 1213.3 & 1205.0 & 1197.2 & 1189.59 & 1182.1 & 1175.4 & 1168.2 & \\
\hline 5.00 & 1239.8 & 1231.0 & 1222.8 & 1213.9 & 1205.6 & 1197.9 & 1190.28 & 1182.8 & 1176.0 & 1169.0 & \\
\hline 10.0 & 1242.4 & 1233.7 & 1225.7 & 1216.8 & 1208.7 & 1201.0 & 1193.60 & 1186.2 & 1179.5 & 1172.4 & \\
\hline
\end{tabular}

of both ILs is inferior to $100 \mathrm{mPa} \cdot \mathrm{s}$, there is an average density uncertainty of $0.3 \mathrm{~kg} \cdot \mathrm{m}^{-3}$ for both. For other ILs and/or other higher pressures where the viscosity increases, the correction value of $0.5 \mathrm{~kg} \cdot \mathrm{m}^{-3}$ was assumed, being inferior to the uncertainty in the overall density data of $1 \mathrm{~kg} \cdot \mathrm{m}^{-3}$. For that reason, the viscosity corrections were neglected in the present work.

\section{Results and Discussion}

Density Measurements. Density measurements were carried out at temperatures ranging from (293.15 to 393.15) $\mathrm{K}$ and pressures from (0.10 to 10.0$) \mathrm{MPa}$. The experimental data obtained are reported in Tables 1 and 2 for all the ILs studied. For $[\mathrm{bmmim}]\left[\mathrm{PF}_{6}\right]$, the density was measured only for temper- 

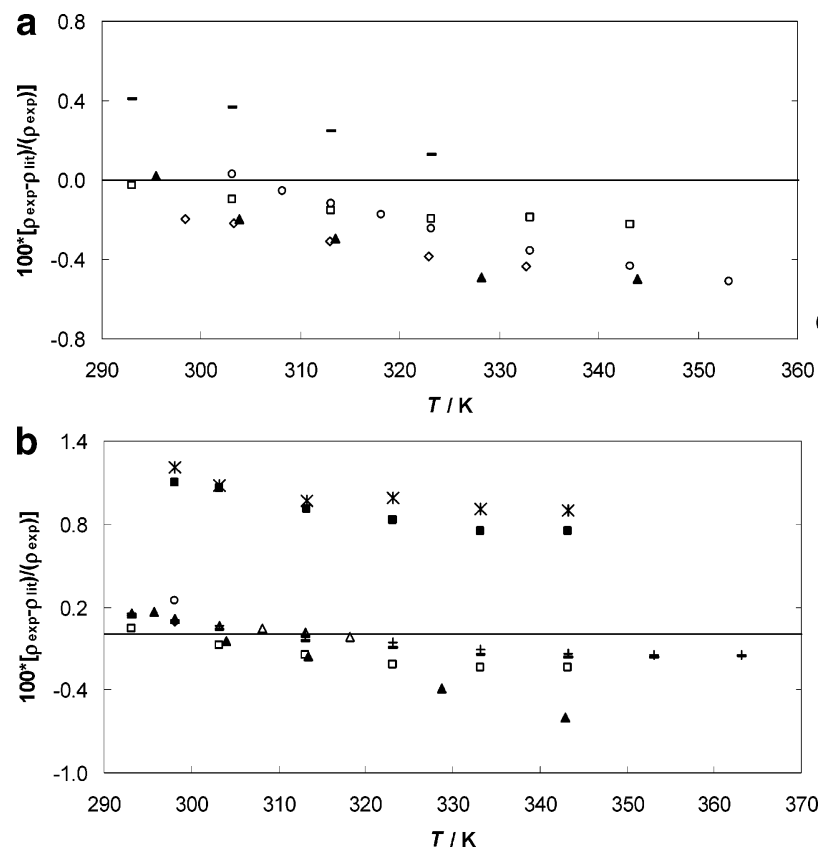

Figure 1. Relative deviations between the experimental density data of this work and those reported in the literature as a function of temperature. (a) $\left[\right.$ bmim] $\left[\mathrm{BF}_{4}\right]$ at $0.10 \mathrm{MPa}: \Delta$, ref $4 ; \square$, ref 6 ; $\diamond$, ref 22 ; $\bigcirc$, ref 23. $[\mathrm{bmim}]\left[\mathrm{BF}_{4}\right]$ at $10.0 \mathrm{MPa}:-$, ref 22. (b) $[\mathrm{bmim}]\left[\mathrm{CF}_{3} \mathrm{SO}_{3}\right]$ at $0.10 \mathrm{MPa}$ : $\Delta$, ref $4 ; \square$, ref 6 . [omim] $\left[\mathrm{BF}_{4}\right]$ at $0.10 \mathrm{MPa}: *$, ref 24; -, ref 25. [hmim]$\left[\mathrm{PF}_{6}\right]$ at $0.10 \mathrm{MPa}: \triangle$, ref $26 ; \mathrm{O}$, ref 27 . [omim] $\left[\mathrm{PF}_{6}\right]$ at $0.10 \mathrm{MPa}: \mathbf{\square}$, ref $24 ;+$, ref $25 ; \bullet$, ref 27.

atures higher than $313.15 \mathrm{~K}$ due to the high melting point of this compound $(\approx 303.15 \mathrm{~K})$.

Density data for some of the studied ILs are already available in the open literature but almost only at atmospheric pressure, ${ }^{4,6,22-27}$ and the relative deviations between the experimental data obtained in this work and those reported by the other authors at $0.10 \mathrm{MPa}$ and from this work and Azevedo et al. ${ }^{22}$ at $10.0 \mathrm{MPa}$ are presented in Figure 1. The figure shows that no systematic errors are present, where the maximum deviations found are in the order of 1.2 and $1.1 \%$ for [omim] $\left[\mathrm{BF}_{4}\right]$ and [omim] $\left[\mathrm{PF}_{6}\right]$, respectively, and appearing at the lower temperatures in respect to $\mathrm{Gu}$ and Brennecke. ${ }^{24}$ However, a better agreement can be observed at higher temperatures. In general, the deviations from our data and the literature range from $(-0.6$ to 1.2$) \%$, and they can be due essentially to the salts purity including water and halides content and also from the experimental technique adopted.

From the experimental densities for a given anion, it is observed that as the alkyl chain length in the imidazolium cation increases, the density of the corresponding IL decreases. The inclusion of a new third substitution in the imidazolium cation of $[\mathrm{bmmim}]\left[\mathrm{PF}_{6}\right]$ follows the same trend, presenting lower densities when compared to $[\mathrm{bmim}]\left[\mathrm{PF}_{6}\right]$ reported by Azevedo et al. ${ }^{22}$ and higher density values when compared to [hmim]$\left[\mathrm{PF}_{6}\right]$ and $[\mathrm{omim}]\left[\mathrm{PF}_{6}\right]$. The average change of $(33.88 \pm 0.01)$ $\mathrm{cm}^{3} \cdot \mathrm{mol}^{-1}$ by the addition of two $-\mathrm{CH}_{2}$ groups observed in the measured data is in good agreement with those reported by Azevedo et al. ${ }^{22,28}$ and Esperança et al. ${ }^{29}$ and are anion independent.

The molar volumes for a series of ILs with the same cation seem to increase with the effective anion size from $\left[\mathrm{BF}_{4}\right]<$ $\left[\mathrm{PF}_{6}\right]<\left[\mathrm{CF}_{3} \mathrm{SO}_{3}\right]$. Due to differences in molecular weight, this effect is not directly translated in a similar dependence in the densities.
Table 3. Effective Molar Volume of Anion $\left(V_{\mathrm{a}}^{*}\right)$ and Cation $\left(V_{\mathrm{c}}\right)$ and Estimated Molar Volumes $\left(V_{\mathrm{m}}\right)$ at $298.15 \mathrm{~K}$

\begin{tabular}{|c|c|c|c|c|c|c|}
\hline \multirow[b]{2}{*}{ anion } & $V_{\mathrm{a}}^{*}$ & \multirow[b]{2}{*}{ cation } & \multirow{2}{*}{$\frac{V_{\mathrm{c}}^{*}}{\mathrm{~cm}^{3} \cdot \mathrm{mol}^{-1}}$} & \multirow{2}{*}{$\frac{\text { estd } V_{\mathrm{m}}}{\mathrm{cm}^{3} \cdot \mathrm{mol}^{-1}}$} & \multirow{2}{*}{$\frac{\operatorname{exptl} V_{\mathrm{m}}}{\mathrm{cm}^{3} \cdot \mathrm{mol}^{-1}}$} & \multirow{2}{*}{$\begin{array}{l}\% \text { of } V_{\mathrm{m}} \\
\text { relative } \\
\text { deviation }\end{array}$} \\
\hline & $\mathrm{cm}^{3} \cdot \mathrm{mol}^{-1}$ & & & & & \\
\hline$\left[\mathrm{BF}_{4}\right]$ & 53.4 & [bmim] & 133.58 & 187.0 & 187.9 & 0.5 \\
\hline$\left[\mathrm{BF}_{4}\right]$ & 53.4 & [omim] & 202.34 & 255.7 & 255.4 & 0.1 \\
\hline$\left[\mathrm{CF}_{3} \mathrm{SO}_{3}\right]$ & $88.0^{a}$ & [bmim] & 133.58 & & 221.5 & \\
\hline$\left[\mathrm{PF}_{6}\right]$ & 73.7 & [bmmim] & $147.33^{a}$ & & 221.0 & \\
\hline$\left[\mathrm{PF}_{6}\right]$ & 73.7 & [hmim] & 167.96 & 241.7 & 241.1 & 0.2 \\
\hline$\left[\mathrm{PF}_{6}\right]$ & 73.7 & [omim] & 202.34 & 276.0 & 274.8 & 0.4 \\
\hline
\end{tabular}

${ }^{a}$ Estimated in this work.

For the most hydrophobic IL, $\left[\mathrm{omim}_{[}\left[\mathrm{PF}_{6}\right]\right.$, an increase of the mass fraction water content of $(11905 \pm 98) \times 10^{-6}$ causes an average density decrease of $0.53 \%$ as compared to the dry IL. The water content does not affect the $\left[\mathrm{omim}_{[}\right]\left[\mathrm{PF}_{6}\right]$ density across the pressure and temperature range investigated as much as other properties such as viscosity and surface tensions. ${ }^{11-12,30}$

Esperança et al. ${ }^{29}$ have demonstrated the ability of a simple model for ILs molar volume prediction, where the molar volume $\left(V_{\mathrm{m}}\right)$ of a given IL is considered as the sum of the effective molar volumes occupied by the cation $\left(V_{\mathrm{c}}^{*}\right)$ and the anion $\left(V_{\mathrm{a}}^{*}\right)$ :

$$
V_{\mathrm{m}}=V_{\mathrm{c}}^{*}+V_{\mathrm{a}}^{*}
$$

Using this approach, for a given ionic liquid knowing the effective size of the anion, it is possible to determine the molar volume of the cation and vice-versa. Moreover, it was verified that there is a proportional increment with the methyl groups and that is irrespective to the anion identity. Thus, it was possible to use the molar volumes presented by Esperança et al. ${ }^{29}$ for the estimation of the volume of a new anion group $\left(\left[\mathrm{CF}_{3} \mathrm{SO}_{3}\right]\right)$ and a new cation group ([bmmim]). The effective molar volumes of these new groups are reported in Table 3 along with predictions to the molar volumes of the studied ILs. Deviations from experimental values are less than $0.5 \%$, showing the good predictive capability of this simple model.

Thermodynamic Properties. The experimental density values can be used to derive some thermodynamic properties, such as the isothermal compressibility $\left(\kappa_{T}\right)$, the isobaric thermal expansion coefficient $\left(\alpha_{p}\right)$, the thermal pressure coefficient $\left(\gamma_{p}\right)$, and the heat capacity pressure dependence $\left(\Delta C_{p}\right)$.

The fitting of the isobaric density data was performed using a Tait equation ${ }^{13}$ as described by

$$
\rho=\rho^{*}-A \ln \left(\frac{(B+0.1) / \mathrm{MPa}}{(B+p) / \mathrm{MPa}}\right)
$$

where $\rho^{*}$ is the density at a given temperature and at a reference pressure of $0.1 \mathrm{MPa}$, and $A$ and $B$ are coefficients of the Tait equation ${ }^{13}$ that are temperature- and IL-dependent. This equation is known to represent very well the density behavior of liquids over pressure at constant temperature. The correlation parameters for each isotherm and the maximum relative deviations from experimental data are reported in Tables 4 and 5. The experimental density isotherms for $[\mathrm{bmim}]\left[\mathrm{CF}_{3} \mathrm{SO}_{3}\right]$ along with the fitting lines obtained with eq 5 are illustrated in Figure 2.

The Tait equation was found to adequately describe the dry ILs isothermal experimental densities with a maximum deviation of $0.02 \%$. Much larger deviations for the densities of the watersaturated $[\mathrm{omim}]\left[\mathrm{PF}_{6}\right]$ were observed with maximum deviations from experimental data of $1.2 \%$. The Tait equation is an integrated form of an empirical equation representative of the isothermal compressibility behavior versus pressure. The effect of pressure in density is best described by the isothermal 
Table 4. Coefficients of the Tait Equation (eq 5 ) for the Density at Each Isotherm between $\left(0.10\right.$ and 10.0) MPa for $[\mathrm{bmim}]\left[\mathrm{BF}_{4}\right]$, [omim] $\left[\mathrm{BF}_{4}\right]$, and $[\mathrm{bmim}]\left[\mathrm{CF}_{3} \mathrm{SO}_{3}\right]$

\begin{tabular}{|c|c|c|c|c|c|c|c|}
\hline$T$ & $A$ & $B$ & \multirow{2}{*}{$\begin{array}{l}\% \text { max } \\
\text { relative } \\
\text { deviation }\end{array}$} & $T$ & A & $B$ & \multirow{2}{*}{$\begin{array}{l}\% \text { max } \\
\text { relative } \\
\text { deviatior }\end{array}$} \\
\hline $\mathrm{K}$ & $\overline{\mathrm{kg} \cdot \mathrm{m}^{-3}}$ & $\mathrm{MPa}$ & & $\mathrm{K}$ & $\overline{\mathrm{kg} \cdot \mathrm{m}^{-3}}$ & $\mathrm{MPa}$ & \\
\hline \multicolumn{8}{|c|}{$[\mathrm{bmim}]\left[\mathrm{BF}_{4}\right]$} \\
\hline 293.15 & 40.43 & 85.94 & 0.0017 & 353.15 & 26.76 & 47.34 & 0.0005 \\
\hline 303.15 & 41.76 & 86.87 & 0.0008 & 363.15 & 39.25 & 67.75 & 0.0010 \\
\hline 313.15 & 46.73 & 95.41 & 0.0033 & 373.15 & 41.27 & 70.43 & 0.0022 \\
\hline 323.15 & 30.99 & 59.12 & 0.0014 & 383.15 & 45.49 & 74.77 & 0.0013 \\
\hline 333.15 & 29.49 & 54.78 & 0.0008 & 393.15 & 47.88 & 77.59 & 0.0029 \\
\hline 343.15 & 43.25 & 78.30 & 0.0008 & & & & \\
\hline \multicolumn{8}{|c|}{$[\mathrm{omim}]\left[\mathrm{BF}_{4}\right]$} \\
\hline 293.15 & 62.76 & 134.84 & 0.0006 & 353.15 & 64.37 & 108.05 & 0.0004 \\
\hline 303.15 & 61.45 & 122.05 & 0.0008 & 363.15 & 66.05 & 106.66 & 0.0003 \\
\hline 313.15 & 73.92 & 143.10 & 0.0021 & 373.15 & 60.64 & 94.35 & 0.0009 \\
\hline 323.15 & 73.68 & 136.94 & 0.0006 & 383.15 & 65.37 & 97.91 & 0.0002 \\
\hline 333.15 & 73.00 & 132.81 & 0.0008 & 393.15 & 74.61 & 110.71 & 0.0013 \\
\hline 343.15 & 60.94 & 104.76 & 0.0004 & & & & \\
\hline \multicolumn{8}{|c|}{$[\mathrm{bmim}]\left[\mathrm{CF}_{3} \mathrm{SO}_{3}\right]$} \\
\hline 293.15 & 60.33 & 105.54 & 0.0025 & 353.15 & 67.55 & 94.36 & 0.0044 \\
\hline 303.15 & 63.82 & 104.53 & 0.0023 & 363.15 & 66.30 & 90.02 & 0.0018 \\
\hline 313.15 & 58.61 & 96.48 & 0.0005 & 373.15 & 52.38 & 69.40 & 0.0018 \\
\hline 323.15 & 38.87 & 56.30 & 0.0018 & 383.15 & 57.60 & 73.06 & 0.0028 \\
\hline 333.15 & 52.67 & 75.63 & 0.0044 & 393.15 & 67.34 & 85.05 & 0.0024 \\
\hline 343.15 & 40.82 & 56.53 & 0.0030 & & & & \\
\hline
\end{tabular}

Table 5. Coefficients of the Tait Equation (eq 5) for the Density at Each Isotherm between (0.10 and 10.0) MPa for [bmmim] $\mathrm{PF}_{6}$, $\left.[\mathrm{hmim}] \mathrm{PF}_{6}\right]$, and Dry and Water-Saturated [omim] $\left[\mathrm{PF}_{6}\right]$

\begin{tabular}{|c|c|c|c|c|c|c|c|}
\hline$T$ & A & $B$ & \multirow{2}{*}{$\begin{array}{c}\% \text { max } \\
\text { relative } \\
\text { deviation }\end{array}$} & $T$ & A & $B$ & \multirow{2}{*}{$\begin{array}{c}\% \text { max } \\
\text { relative } \\
\text { deviation }\end{array}$} \\
\hline $\mathrm{K}$ & $\overline{\mathrm{kg} \cdot \mathrm{m}^{-3}}$ & $\mathrm{MPa}$ & & $\mathrm{K}$ & $\overline{\mathrm{kg} \cdot \mathrm{m}^{-3}}$ & $\mathrm{MPa}$ & \\
\hline \multicolumn{8}{|c|}{$[\mathrm{bmmim}]\left[\mathrm{PF}_{6}\right]$} \\
\hline 313.15 & 41.35 & 76.13 & 0.0055 & 363.15 & 53.88 & 84.57 & 0.0021 \\
\hline 323.15 & 54.06 & 94.39 & 0.0028 & 373.15 & 43.12 & 65.05 & 0.0159 \\
\hline 333.15 & 38.30 & 66.62 & 0.0016 & 383.15 & 38.14 & 55.15 & 0.0005 \\
\hline 343.15 & 48.67 & 81.81 & 0.0034 & 393.15 & 48.77 & 69.81 & 0.0009 \\
\hline 353.15 & 43.99 & 71.07 & 0.0020 & & & & \\
\hline \multicolumn{8}{|c|}{$[\mathrm{hmim}]\left[\mathrm{PF}_{6}\right]$} \\
\hline 293.15 & 61.71 & 115.45 & 0.0027 & 353.15 & 53.84 & 80.61 & 0.0020 \\
\hline 303.15 & 38.93 & 69.68 & 0.0009 & 363.15 & 49.41 & 68.78 & 0.0033 \\
\hline 313.15 & 54.42 & 93.33 & 0.0006 & 373.15 & 35.19 & 45.90 & 0.0016 \\
\hline 323.15 & 57.67 & 92.33 & 0.0036 & 383.15 & 36.97 & 46.15 & 0.0037 \\
\hline 333.15 & 61.73 & 95.62 & 0.0009 & 393.15 & 62.23 & 75.92 & 0.0005 \\
\hline 343.15 & 30.44 & 46.48 & 0.0011 & & & & \\
\hline \multicolumn{8}{|c|}{ [omim] $\left[\mathrm{PF}_{6}\right]$} \\
\hline 293.15 & 53.59 & 93.49 & 0.0046 & 353.15 & 44.55 & 61.18 & 0.0066 \\
\hline 303.15 & 50.76 & 84.49 & 0.0035 & 363.15 & 48.90 & 66.86 & 0.0053 \\
\hline 313.15 & 47.99 & 75.99 & 0.0040 & 373.15 & 46.99 & 62.62 & 0.0007 \\
\hline 323.15 & 37.16 & 58.61 & 0.0006 & 383.15 & 50.11 & 65.21 & 0.0072 \\
\hline 333.15 & 35.39 & 53.86 & 0.0040 & 393.15 & 46.78 & 56.81 & 0.0046 \\
\hline 343.15 & 39.21 & 56.40 & 0.0022 & & & & \\
\hline \multicolumn{8}{|c|}{ [omim][PF 6 Saturated with Water at $293.15 \mathrm{~K}$} \\
\hline 293.15 & 37.25 & 66.27 & 0.8339 & 343.15 & 54.40 & 79.71 & 1.0604 \\
\hline 303.15 & 50.52 & 84.43 & 0.9071 & 353.15 & 94.06 & 133.91 & 1.1236 \\
\hline 313.15 & 78.49 & 129.15 & 0.9456 & 363.15 & 72.95 & 100.44 & 1.1556 \\
\hline 323.15 & 56.51 & 91.66 & 0.9519 & 373.15 & 71.92 & 98.34 & 1.1720 \\
\hline 333.15 & 73.60 & 114.85 & 1.0064 & 383.15 & 75.67 & 102.15 & 1.1933 \\
\hline
\end{tabular}

compressibility $\left(\kappa_{T}\right)$ that is calculated using the isothermal pressure derivative of density according to the following:

$$
\kappa_{T}=\left(\frac{\partial \ln \rho}{\partial p}\right)_{T}=-\left(\frac{\partial \ln V}{\partial p}\right)_{T}
$$

where $\rho$ is the density and $p$ is the pressure at constant temperature, $T$. The isothermal compressibilities can be thus easily calculated using the fitting of eq 5 to the density data. For illustration purposes the isothermal compressibilities of $[\mathrm{hmim}]\left[\mathrm{PF}_{6}\right]$ are shown in Figure 3. The standard deviations

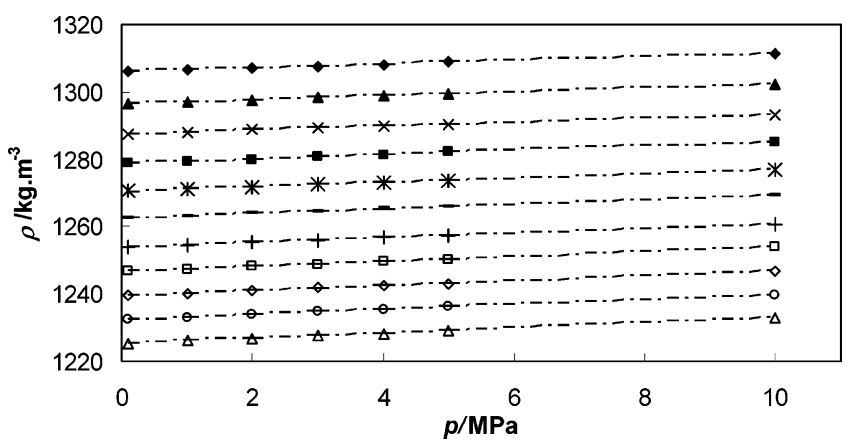

Figure 2. Isotherms of the experimental density of $[\mathrm{bmim}]\left[\mathrm{CF}_{3} \mathrm{SO}_{3}\right]$ : $293.15 \mathrm{~K} ; \boldsymbol{\Delta}, 303.15 \mathrm{~K} ; \times, 313.15 \mathrm{~K} ; \mathbf{\square}, 323.15 \mathrm{~K} ; * 333.15 \mathrm{~K} ;-, 343.15$ $\mathrm{K} ;+, 353.15 \mathrm{~K} ; \square, 363.15 \mathrm{~K} ; \diamond, 373.15 \mathrm{~K} ;$ ○, $383.15 \mathrm{~K} ; \Delta, 393.15 \mathrm{~K}$ The lines correspond to the fit of the data by eq 5 .

presented were calculated with the law of propagation of errors from the standard deviations of each constant of eq 5. Although the associated uncertainty is quite large, as shown by the error bars in Figure 3, it seems that the ILs become more compressible with increasing temperatures. On the other hand, it would seem that the ILs become less compressible with increasing pressure, but if the large standard deviations associated with these values are considered, the isothermal compressibilities should be considered constant in the pressure range studied. For [hmim]$\left[\mathrm{PF}_{6}\right]$ the isothermal compressibilities range from $(0.41 \pm 0.14)$ $\mathrm{GPa}^{-1}$ at $293.15 \mathrm{~K}$ to $(0.66 \pm 0.02) \mathrm{GPa}^{-1}$ at $393.15 \mathrm{~K}$ and at a constant pressure of 1.0 MPa. The ILs isothermal compressibilities are similar to those of water and high-temperature molten salts and are less compressible than organic solvents due to the strong Coulombic interactions between the ions. ${ }^{15,24}$

For $[$ bmim $]\left[\mathrm{BF}_{4}\right]$ in the range (303.15 to 323.15$) \mathrm{K}$ and $(0.1$ to 10.0) $\mathrm{MPa}$, we have an average deviation of isothermal compressibilities of $-3 \%$ from Azevedo et al. ${ }^{22}$ For [omim]$\left[\mathrm{BF}_{4}\right]$ and $[\mathrm{omim}]\left[\mathrm{PF}_{6}\right]$ at $0.10 \mathrm{MPa}$ and $323.15 \mathrm{~K}$, we found a deviation of $-21 \%$ and $5 \%$, respectively, from the data reported by $\mathrm{Gu}$ and Brennecke. ${ }^{24}$ It should be noted that there is a strong dependence of the derivation method from the fitting to the experimental data. To determine accurate derivative properties, a large number of experimental density points should be collected.

Unfortunately, there is no expression analogous to the Tait equation to adequately describe the volume variations versus temperature at constant pressure. For those situations where the statistical scatter of the raw data is large as compared to an unambiguous determination of the curvature, the use of $\ln (\rho)$ $=f(T)$ is recommended because it avoids the mathematical violation that can arise from the assumption of considering the density as a linear function of temperature, and the isobaric expansivity is described by

$$
\alpha_{p}=-\left(\frac{\partial \ln \rho}{\partial T}\right)_{p}=\left(\frac{\partial \ln V}{\partial T}\right)_{p}
$$

where $\rho$ is the density and $T$ is the temperature at constant pressure, $p$. If this function is linear, then $\ln (V)=f(T)$ is also linear, and $\alpha_{\mathrm{p}}$ is constant since it is temperature-independent. To investigate the $\alpha_{p}$ dependence with temperature relative to other compounds reported in literature, ${ }^{22,24,28,29}$ a second-order polynomial function for the temperature dependence of the $\ln (\rho)$ was chosen:

$$
\ln \left(\frac{\rho}{\rho_{0}}\right)=C+D(T)+E(T)^{2}
$$




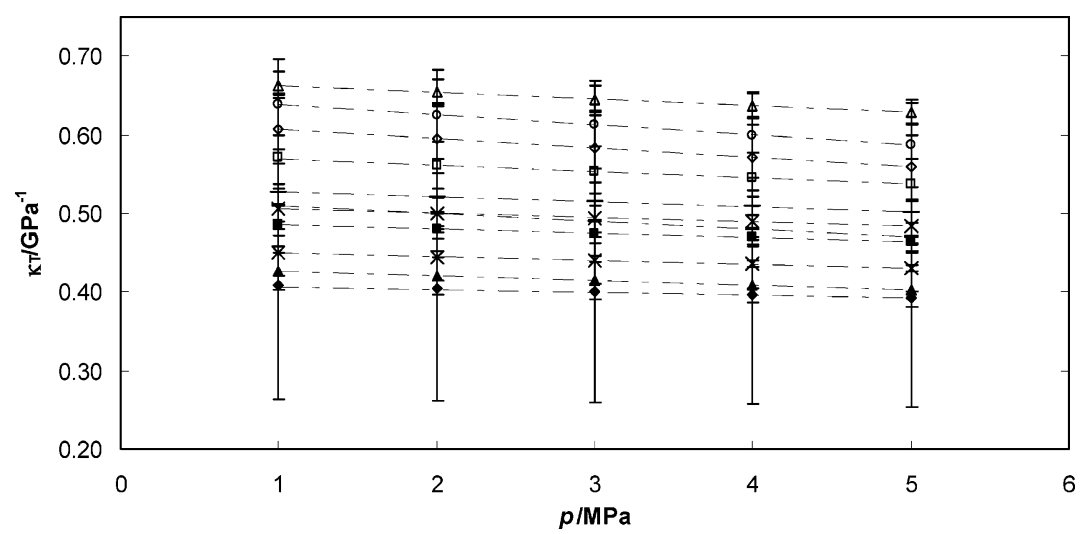

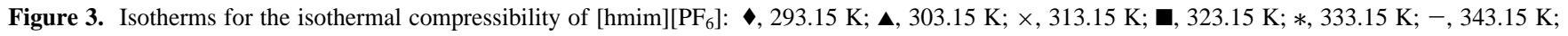
,$+ 353.15 \mathrm{~K} ; \square, 363.15 \mathrm{~K} ; \diamond, 373.15 \mathrm{~K} ; \bigcirc, 383.15 \mathrm{~K} ; \Delta, 393.15 \mathrm{~K}$.

Table 6. Parameters of the Isobaric Second-Order Polynomial Fitting (eq 8) for [bmim] $\left[\mathrm{BF}_{4}\right]$, [omim] $\left[\mathrm{BF}_{4}\right]$, and $[\mathrm{bmim}]\left[\mathrm{CF}_{3} \mathrm{SO}_{3}\right]$

\begin{tabular}{cccc}
\hline$p / \mathrm{MPa}$ & $C \pm \sigma^{a}$ & $10^{3}\left(D \pm \sigma^{a}\right) / \mathrm{K}^{-1}$ & $10^{7}\left(E \pm \sigma^{a}\right) / \mathrm{K}^{-2}$ \\
\hline & & \\
0.10 & $7.373 \pm 0.004$ & $-1.20 \pm 0.03$ & $8.6 \pm 0.4$ \\
1.00 & $7.373 \pm 0.004$ & $-1.20 \pm 0.03$ & $8.6 \pm 0.4$ \\
2.00 & $7.372 \pm 0.005$ & $-1.19 \pm 0.03$ & $8.6 \pm 0.4$ \\
3.00 & $7.372 \pm 0.004$ & $-1.19 \pm 0.03$ & $8.6 \pm 0.4$ \\
4.00 & $7.372 \pm 0.004$ & $-1.19 \pm 0.03$ & $8.6 \pm 0.4$ \\
5.00 & $7.373 \pm 0.004$ & $-1.19 \pm 0.03$ & $8.6 \pm 0.4$ \\
10.0 & $7.374 \pm 0.004$ & $-1.19 \pm 0.03$ & $8.8 \pm 0.4$ \\
& & {$\left[\mathrm{omim}_{4}\right]\left[\mathrm{BF}_{4}\right]$} & \\
0.10 & $7.319 \pm 0.003$ & $-1.36 \pm 0.02$ & $10.7 \pm 0.3$ \\
1.00 & $7.318 \pm 0.003$ & $-1.36 \pm 0.02$ & $10.7 \pm 0.3$ \\
2.00 & $7.318 \pm 0.004$ & $-1.36 \pm 0.02$ & $10.7 \pm 0.3$ \\
3.00 & $7.318 \pm 0.004$ & $-1.36 \pm 0.02$ & $10.7 \pm 0.3$ \\
4.00 & $7.318 \pm 0.004$ & $-1.35 \pm 0.02$ & $10.7 \pm 0.3$ \\
5.00 & $7.317 \pm 0.004$ & $-1.35 \pm 0.02$ & $10.6 \pm 0.3$ \\
10.0 & $7.316 \pm 0.004$ & $-1.34 \pm 0.02$ & $10.6 \pm 0.4$ \\
& & {$[\mathrm{bmim}]\left[\mathrm{CF}_{3} \mathrm{SO}_{3}\right]$} & \\
0.10 & $7.464 \pm 0.007$ & $-1.25 \pm 0.04$ & $8.9 \pm 0.6$ \\
1.00 & $7.464 \pm 0.006$ & $-1.25 \pm 0.04$ & $9.0 \pm 0.6$ \\
2.00 & $7.463 \pm 0.007$ & $-1.24 \pm 0.04$ & $8.8 \pm 0.6$ \\
3.00 & $7.461 \pm 0.007$ & $-1.23 \pm 0.04$ & $8.7 \pm 0.6$ \\
4.00 & $7.461 \pm 0.007$ & $-1.22 \pm 0.04$ & $8.7 \pm 0.6$ \\
5.00 & $7.460 \pm 0.006$ & $-1.22 \pm 0.04$ & $8.7 \pm 0.6$ \\
10.0 & $7.458 \pm 0.007$ & $-1.20 \pm 0.04$ & $8.5 \pm 0.6$
\end{tabular}

${ }^{a}$ Standard deviation.

where $\rho$ is the experimental density at each pressure and temperature; $\rho_{0}$ is assumed to be $1.0 \mathrm{~kg} \cdot \mathrm{m}^{-3} ; T$ is the temperature; and $C, D$, and $E$ are constant parameters determined from the experimental data using a second-order polynomial equation at constant pressure, $p$. The fitting coefficients of the second-order polynomial equation for each IL at constant pressure are presented in Tables 6 and 7 .

Using eqs 7 and 8 , the following equation is obtained:

$$
\alpha_{\mathrm{p}}=-(D+2 E(T))
$$

At first approach, $\alpha_{p}$ seems to decrease with temperature as shown in Figure 4 for [omim] $\left[\mathrm{BF}_{4}\right]$. However, if the standard deviations determined with the law of propagation of errors from the standard deviation coupled to each parameter adjustment on this property are considered, they are shown to be very large, and no statistically significant temperature dependence can be assigned to this property for most of the ILs studied, even in the large temperature range used in this work. It can nevertheless be shown that the ILs studied do not notably expand with temperature.

However, there are some ILs that present more significative decreases in $\alpha_{p}$ with temperature, if obtained from eq 9, but in
Table 7. Parameters of the Isobaric Second-Order Polynomial Fitting (eq 8) for $\left[\mathrm{bmmim}_{[}\left[\mathrm{PF}_{6}\right],[\mathrm{hmim}]\left[\mathrm{PF}_{6}\right]\right.$, and Dry and Water-Saturated [omim] $\left[\mathbf{P F}_{6}\right]$

\begin{tabular}{|c|c|c|c|}
\hline$p / \mathrm{MPa}$ & $C \pm \sigma^{a}$ & $10^{3}\left(D \pm \sigma^{a}\right) / \mathrm{K}^{-1}$ & $10^{7}\left(E \pm \sigma^{a}\right) / \mathrm{K}^{-2}$ \\
\hline \multicolumn{4}{|c|}{$[\mathrm{bmmim}]\left[\mathrm{PF}_{6}\right]$} \\
\hline 0.10 & $7.51 \pm 0.01$ & $-1.30 \pm 0.07$ & $9.9 \pm 0.9$ \\
\hline 1.00 & $7.51 \pm 0.01$ & $-1.29 \pm 0.07$ & $9.7 \pm 0.9$ \\
\hline 2.00 & $7.51 \pm 0.01$ & $-1.31 \pm 0.07$ & $10.1 \pm 0.9$ \\
\hline 3.00 & $7.51 \pm 0.01$ & $-1.31 \pm 0.07$ & $10.0 \pm 0.9$ \\
\hline 4.00 & $7.51 \pm 0.01$ & $-1.30 \pm 0.07$ & $10.0 \pm 0.9$ \\
\hline 5.00 & $7.51 \pm 0.01$ & $-1.30 \pm 0.07$ & $10.0 \pm 0.9$ \\
\hline 10.0 & $7.51 \pm 0.01$ & $-1.30 \pm 0.08$ & $10.0 \pm 0.9$ \\
\hline \multicolumn{4}{|c|}{$[\mathrm{hmim}]\left[\mathrm{PF}_{6}\right]$} \\
\hline 0.10 & $7.467 \pm 0.004$ & $-1.29 \pm 0.02$ & $9.5 \pm 0.3$ \\
\hline 1.00 & $7.468 \pm 0.004$ & $-1.30 \pm 0.02$ & $9.6 \pm 0.4$ \\
\hline 2.00 & $7.468 \pm 0.004$ & $-1.30 \pm 0.03$ & $9.7 \pm 0.4$ \\
\hline 3.00 & $7.469 \pm 0.004$ & $-1.30 \pm 0.03$ & $9.8 \pm 0.4$ \\
\hline 4.00 & $7.469 \pm 0.004$ & $-1.30 \pm 0.03$ & $9.8 \pm 0.4$ \\
\hline 5.00 & $7.470 \pm 0.005$ & $-1.31 \pm 0.03$ & $9.9 \pm 0.4$ \\
\hline 10.0 & $7.474 \pm 0.005$ & $-1.33 \pm 0.03$ & $10.3 \pm 0.5$ \\
\hline \multicolumn{4}{|c|}{$[\mathrm{omim}]\left[\mathrm{PF}_{6}\right]$} \\
\hline 0.10 & $7.403 \pm 0.009$ & $-1.18 \pm 0.05$ & $7.9 \pm 0.7$ \\
\hline 1.00 & $7.405 \pm 0.009$ & $-1.19 \pm 0.05$ & $8.1 \pm 0.7$ \\
\hline 2.00 & $7.404 \pm 0.008$ & $-1.18 \pm 0.05$ & $8.0 \pm 0.7$ \\
\hline 3.00 & $7.405 \pm 0.008$ & $-1.19 \pm 0.05$ & $8.1 \pm 0.7$ \\
\hline 4.00 & $7.404 \pm 0.008$ & $-1.18 \pm 0.05$ & $8.1 \pm 0.7$ \\
\hline 5.00 & $7.404 \pm 0.008$ & $-1.18 \pm 0.05$ & $8.1 \pm 0.7$ \\
\hline 10.0 & $7.408 \pm 0.008$ & $-1.20 \pm 0.04$ & $8.5 \pm 0.6$ \\
\hline \multicolumn{4}{|c|}{ [omim] $\left[\mathrm{PF}_{6}\right]$ Saturated with Water at $293.15 \mathrm{~K}$} \\
\hline 0.10 & $7.417 \pm 0.009$ & $-1.27 \pm 0.04$ & $9.0 \pm 0.6$ \\
\hline 1.00 & $7.416 \pm 0.009$ & $-1.27 \pm 0.04$ & $9.0 \pm 0.6$ \\
\hline 2.00 & $7.416 \pm 0.008$ & $-1.27 \pm 0.04$ & $8.9 \pm 0.5$ \\
\hline 3.00 & $7.415 \pm 0.008$ & $-1.26 \pm 0.04$ & $8.9 \pm 0.6$ \\
\hline 4.00 & $7.414 \pm 0.008$ & $-1.25 \pm 0.04$ & $8.8 \pm 0.5$ \\
\hline 5.00 & $7.413 \pm 0.008$ & $-1.25 \pm 0.04$ & $8.8 \pm 0.5$ \\
\hline 10.0 & $7.409 \pm 0.008$ & $-1.22 \pm 0.03$ & $8.5 \pm 0.6$ \\
\hline
\end{tabular}

fact, ILs seem to not expand markedly with temperature. The present $\alpha_{p}$ values are lower than most organic liquids and similar to those of water at temperatures where the working fluids are in the liquid state. ${ }^{15}$ From eq 9 , for $[\mathrm{omim}]\left[\mathrm{BF}_{4}\right]$ the thermal expansion coefficients range from $(0.72 \pm 0.04) \times 10^{-3} \mathrm{~K}^{-1}$ at $303.15 \mathrm{~K}$ to $(0.54 \pm 0.04) \times 10^{-3} \mathrm{~K}^{-1}$ at $383.15 \mathrm{~K}$ and at a constant pressure of $0.1 \mathrm{MPa}$.

Several authors have determined the thermal expansion coefficient for ILs in common, ${ }^{22,24}$ and an average deviation of $12 \%$ was found with the data for $[\mathrm{bmim}]\left[\mathrm{BF}_{4}\right]$ at several pressures and at $303.15 \mathrm{~K}$ presented by Azevedo et al., ${ }^{22}$ of 6 $\%$ from the $[\mathrm{omim}]\left[\mathrm{BF}_{4}\right]$, and of $12 \%$ from the [omim] $\left[\mathrm{PF}_{6}\right]$ data at $0.10 \mathrm{MPa}$ and several temperatures reported by $\mathrm{Gu}$ and Brennecke. ${ }^{24}$ 


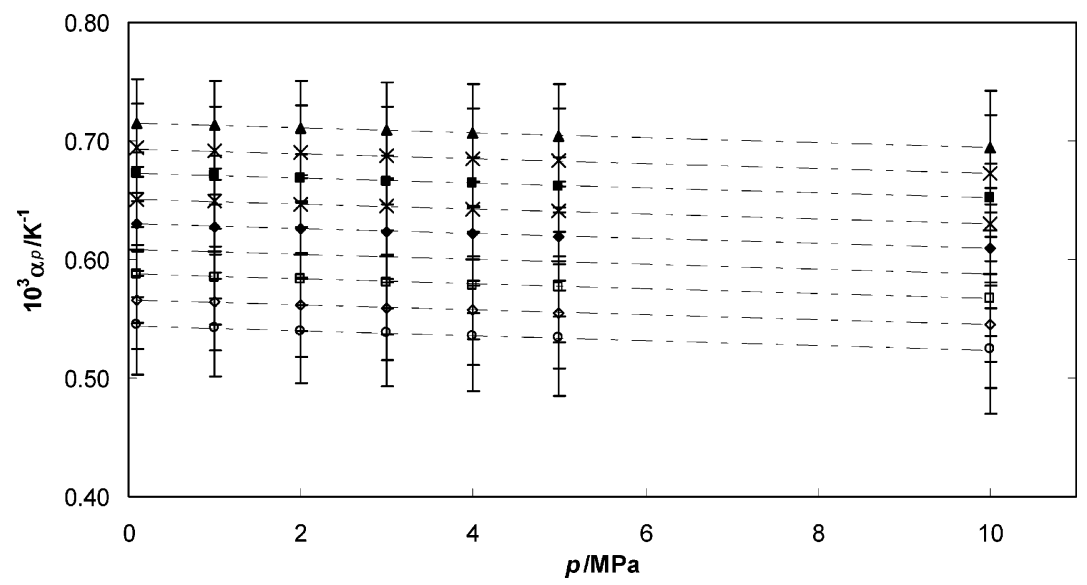

Figure 4. Isotherms for the isobaric expansivity of [omim][BF $]$ : $\mathbf{\Delta}, 303.15 \mathrm{~K} ; \times, 313.15 \mathrm{~K} ; \mathbf{\square}, 323.15 \mathrm{~K} ; *, 333.15 \mathrm{~K} ; \bullet, 343.15 \mathrm{~K}$; +, $353.15 \mathrm{~K}$; $\square$, $363.15 \mathrm{~K} ; \diamond, 373.15 \mathrm{~K} ; \bigcirc, 383.15 \mathrm{~K}$.

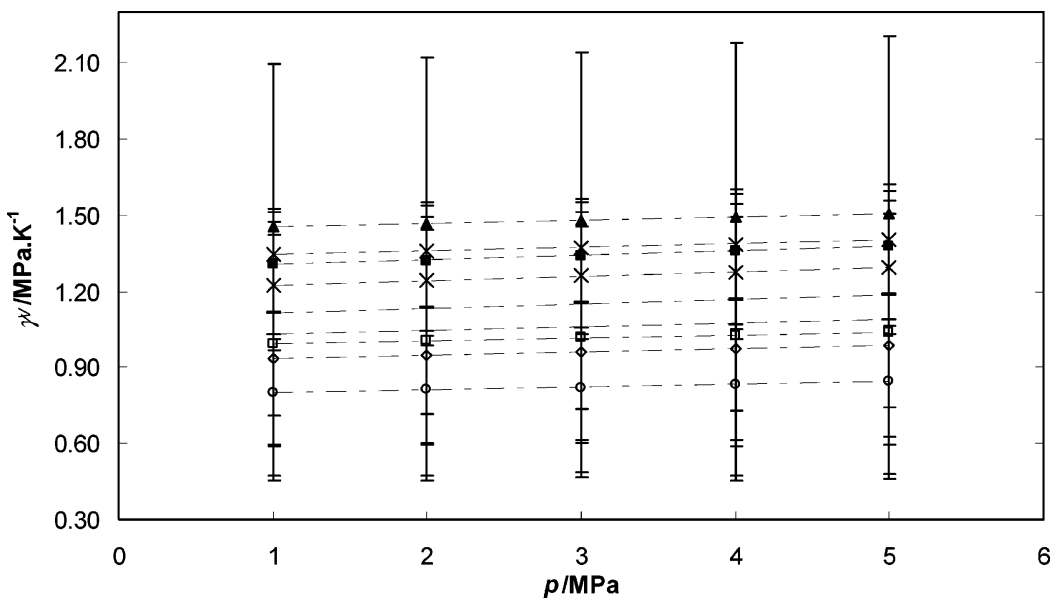

Figure 5. Isotherms for the thermal pressure coefficient of $[\mathrm{omim}]\left[\mathrm{PF}_{6}\right]: \mathbf{\Delta}, 303.15 \mathrm{~K} ; \times, 313.15 \mathrm{~K} ; \mathbf{\square}, 323.15 \mathrm{~K} ; *, 333.15 \mathrm{~K}$; -, $343.15 \mathrm{~K}$; +, 353.15 $\mathrm{K} ; \square, 363.15 \mathrm{~K} ; \diamond, 373.15 \mathrm{~K} ;$ ○, $383.15 \mathrm{~K}$.

The thermal pressure coefficient $\gamma_{\mathrm{V}}$ may be calculated for all the ILs studied according to

$$
\gamma_{\mathrm{V}}=\frac{\alpha_{p}}{\kappa_{T}}
$$

The thermal pressure coefficients as function of pressure obtained for [omim] $\left[\mathrm{PF}_{6}\right]$ as well as the associated uncertainties are depicted in Figure 5. The $\gamma_{\mathrm{V}}$ decreases with temperature and increases slightly with pressure for all the ILs studied, if the standard deviations are not taken into account. However, if this is done, it can be seen that the $\gamma_{\mathrm{V}}$ is almost constant in the temperature and pressure range studied. The standard deviations were determined with the law of propagation of errors from the standard deviations of $\alpha_{p}$ and $\kappa_{T}$.

A comparison for the isothermal compressibilities and isobaric thermal expansivities as a function of temperature at a constant pressure of 5.0 MPa for the ILs studied is presented in Figure 6 . The standard deviations were not included in these derived properties in order to facilitate the identification of the ILs; however it should be noted that as mentioned before they are as large as shown in Figures 3 and 4. Some conclusions can nevertheless be drawn. From Figure 6a, there is an indication that the ILs with higher molar volumes are generally more compressible since $\kappa_{T}$ increases with the alkyl chain length of the cation and with the effective anion size. On the other hand, Figure $6 \mathrm{~b}$ shows that the thermal pressure coefficient decreases with the alkyl chain length of the cation and with the effective anion size. For both cases, it can also be seen that there is an increase in the derived properties with the presence of water in the IL.

The isothermal variation of heat capacity with pressure can be calculated with

$$
\left(\frac{\partial C_{p}}{\partial p}\right)_{T}=-T\left(\frac{\partial^{2} V_{\mathrm{m}}}{\partial T^{2}}\right)_{p}
$$

which in combination with eq 7 gives

$$
\left(\frac{\partial C_{p}}{\partial p}\right)_{T}=-T \frac{M}{\rho}\left[\left(\frac{\partial \alpha_{p}}{\partial T}\right)_{p}+\left(\alpha_{p}\right)^{2}\right]
$$

where $C_{p}$ is the isobaric heat capacity, $p$ is the pressure, $T$ is the temperature, $M$ is the relative molecular mass, and $\alpha_{p}$ is the thermal expansion coefficient determined by eq 9 . The integration of eq 12 gives

$$
\begin{aligned}
C_{p}(T, p)-C_{p}\left(T, p^{*}\right)= & \\
& -T \int_{p^{*}}^{p}\left\{\frac{M}{\rho}\left[\left(\frac{\partial \alpha_{p}}{\partial T}\right)_{p}+\left(\alpha_{p}\right)^{2}\right]\right\} \mathrm{d} p
\end{aligned}
$$

where $p^{*}$ is the reference pressure $\left(p^{*}=0.1 \mathrm{MPa}\right)$.

The differences between the isobaric heat capacities at a reference pressure and at a given pressure $p$ are approximately 
Table 8. Values of $C_{p}$ Variations (eq 13) between (0.10 and 10.0) MPa for [bmim] $\left[\mathrm{BF}_{4}\right]$, [omim] $\left[\mathrm{BF}_{4}\right],[\mathrm{bmim}]\left[\mathrm{CF}_{3} \mathrm{SO}_{3}\right],[\mathrm{bmmim}]\left[\mathrm{PF}_{6}\right]$, $[\mathrm{hmim}]\left[\mathrm{PF}_{6}\right]$, and $[0 \mathrm{mim}]\left[\mathrm{PF}_{6}\right]$

\begin{tabular}{|c|c|c|c|c|c|c|c|c|c|c|}
\hline \multicolumn{11}{|c|}{$\Delta C_{p} /\left(\mathrm{J} \cdot \mathrm{mol}^{-1} \cdot \mathrm{K}^{-1}\right)$ at $T / \mathrm{K}$} \\
\hline 293.15 & 303.15 & 313.15 & 323.15 & 333.15 & 343.15 & 353.15 & 363.15 & 373.15 & 383.15 & 393.15 \\
\hline 0.702 & 0.744 & 0.787 & 0.831 & 0.876 & $\begin{array}{c}{[\mathrm{bmim}]\left[\mathrm{BF}_{4}\right]} \\
0.921\end{array}$ & 0.968 & 1.014 & 1.062 & 1.110 & 1.159 \\
\hline 1.189 & 1.261 & 1.335 & 1.410 & 1.487 & $\underset{1.564}{[\mathrm{omim}]\left[\mathrm{BF}_{4}\right]}$ & 1.643 & 1.722 & 1.803 & 1.884 & 1.967 \\
\hline \multirow[t]{2}{*}{0.770} & 0.818 & 0.867 & 0.916 & 0.967 & $\begin{array}{c}{[\mathrm{bmim}]\left[\mathrm{CF}_{3} \mathrm{SO}_{3}\right]} \\
1.018\end{array}$ & 1.072 & 1.125 & 1.179 & 1.234 & 1.290 \\
\hline & & 1.083 & 1.144 & 1.207 & $\begin{array}{c}{[\mathrm{bmmim}]} \\
1.270\end{array}$ & 1.334 & 1.399 & 1.465 & 1.531 & 1.599 \\
\hline 1.076 & 1.142 & 1.209 & 1.277 & 1.347 & $\begin{array}{c}{[\mathrm{hmim}]\left[\mathrm{PF}_{6}\right]} \\
1.418\end{array}$ & 1.491 & 1.563 & 1.637 & 1.712 & 1.787 \\
\hline 0.954 & 1.013 & 1.073 & 1.135 & 1.198 & $\begin{array}{c}\text { [omim] }\left[\mathrm{PF}_{6}\right] \\
1.262\end{array}$ & 1.327 & 1.393 & 1.461 & 1.529 & 1.598 \\
\hline
\end{tabular}

linear. Results are presented in Table 8 for the highest pressure studied. Due to the larger values of the experimental $C_{p}$ data, ${ }^{4,31}$ the $\Delta C_{p}$ of ILs are negligible except for very high pressures far outside the pressure range studied.
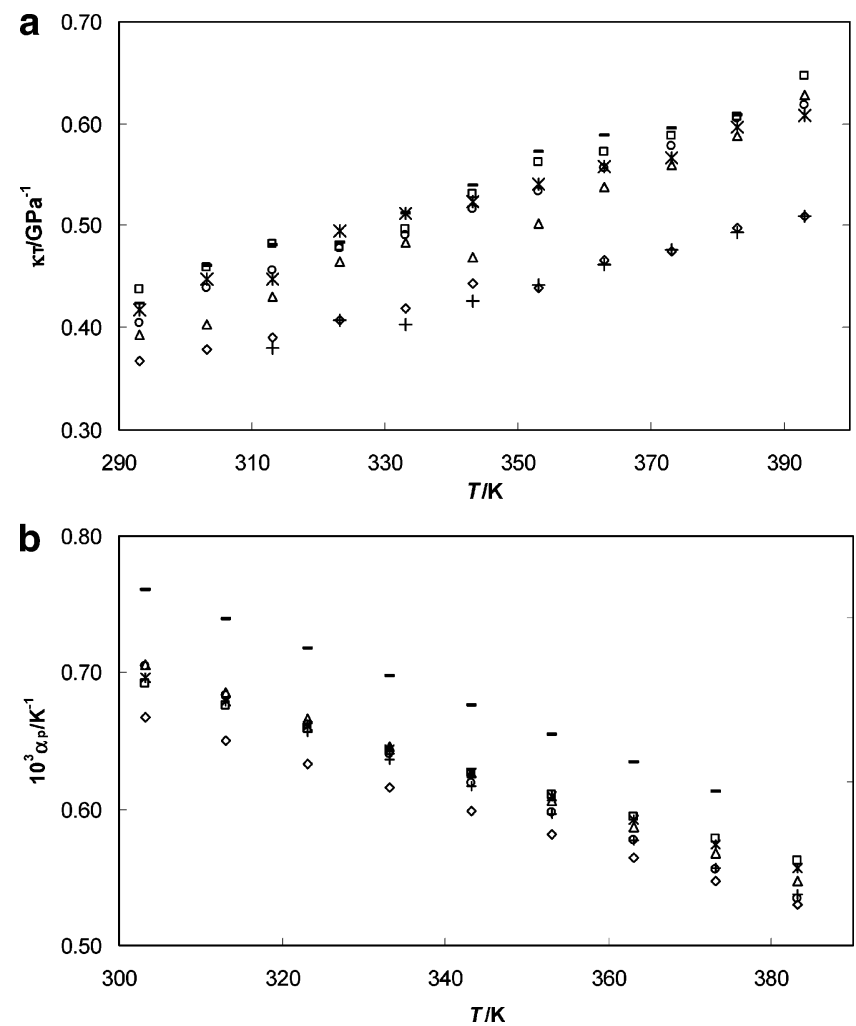

Figure 6. (a) Isothermal compressibility at $5.0 \mathrm{MPa}$ as a function of temperature. (b) Thermal expansion coefficient at $5.0 \mathrm{MPa}$ as a function of temperature: $\diamond,[\mathrm{bmim}]\left[\mathrm{BF}_{4}\right] ; \bigcirc,[\mathrm{omim}]\left[\mathrm{BF}_{4}\right] ; *,[\mathrm{bmim}]\left[\mathrm{CF}_{3} \mathrm{SO}_{3}\right] ;+$, $[\mathrm{bmmim}]\left[\mathrm{PF}_{6}\right] ; \triangle,[\mathrm{hmim}]\left[\mathrm{PF}_{6}\right] ; \square,[\mathrm{omim}]\left[\mathrm{PF}_{6}\right]$ dried; - , [omim] $\left[\mathrm{PF}_{6}\right]$ saturated with water at $293.15 \mathrm{~K}$.

\section{Conclusions}

Experimental density data for six pure ILs in the temperature range (293.15 to 393.15$) \mathrm{K}$ and pressure range (0.10 to 10.0$)$ $\mathrm{MPa}$ are presented, and the water content influence in the density of the most hydrophobic IL was also assessed. Density results show that it can be tailored by structural variations in the cation and anion. From the experimental data, a proportional molar volume increase with the $-\mathrm{CH}_{2}$ addition to the alkyl chain length of the 1- $\mathrm{C}_{n}$-3-methylimidazolium-based ILs was observed, and a molar volume increase with the effective anion size was also observed. A simple ideal-volume model previously proposed $^{29}$ was employed for the prediction of the imidazolium molar volumes at ambient conditions and proved to agree well with the experimental results. Water content, anion identity, and alkyl chain length can be a significant factor when considering the applications of a particular IL.

The liquid densities were correlated with the Tait equation ${ }^{13}$ that has been shown to describe extremely well all the pure dried ILs studied with deviations from experimental data smaller than $0.02 \%$. However, larger deviations were found for the correlation of the water-saturated IL isothermal densities with the Tait equation, presenting a maximum deviation from the experimental data of $1.2 \%$. The experimental results were also used to derive some thermodynamic properties such as the isothermal compressibility, the isobaric expansivity, the thermal pressure coefficient, and the pressure difference in heat capacities of the studied ILs that are difficult to obtain by direct measurements at extreme conditions of pressure and temperature.

\section{Literature Cited}

(1) Holbrey, J. D.; Seddon, K. R. Ionic liquids. Clean Prod. Proc. 1999, $1,223-236$.

(2) Earle, M. J.; Seddon, K R. Ionic liquids. Green solvents for the future. Pure Appl. Chem. 2000, 72, 1391-1398.

(3) Marsh, K. N.; Boxall, J. A.; Lichtenthaler, R. Room temperature ionic liquids and their mixtures-a review. Fluid Phase Equilib. 2004, 219, 93-98.

(4) Fredakle, C. P.; Crosthwaite, J. M.; Hert, D. G.; Aki, S. N. V. K.; Brennecke, J. F. Thermophysical properties of imidazolium-based ionic liquids. J. Chem. Eng. Data 2004, 49, 954-964.

(5) Anthony, J. L.; Maginn, E. J.; Brennecke, J. F. Solution thermodynamics of imidazolium-based ionic liquids and water. J. Phys. Chem. B 2001, 105, 10942-10949.

(6) Tokuda, H.; Hyamizu, K.; Ishii, K.; Susan, Md. B. H.; Watanabe, M. Physicochemical properties of room temperature ionic liquids. 1. Variation of anionic species. J. Phys. Chem. B 2004, 108, 1659316600.

(7) Tokuda, H.; Hyamizu, K.; Ishii, K.; Susan, Md. B. H.; Watanabe, M. Physicochemical properties and structures of room temperature ionic liquids. 2. Variation of alkyl chain length in imidazolium cation. $J$. Phys. Chem. B 2005, 109, 6103-6110.

(8) Adams, Ch. J.; Earle, M. J.; Seddon, K. R. Catalytic cracking reactions of polyethylene to light alkanes in ionic liquids. Green Chem. 2000, $2,21-24$.

(9) Holbrey, J. D.; Seddon, K. R.; Wareing, R. A simple colorimetric method for the quality control of 1-alkyl-3-methylimidazolium ionic liquid precursors. Green Chem. 2001, 3, 33-36.

(10) Sheldon, R. Catalytic reactions in ionic liquids. Chem. Commun. 2001, 2399-2407.

(11) Seddon, K. R.; Stark, A.; Torres, M. J. Influence of chloride, water, and organic solvents on the physical properties of ionic liquids. Pure Appl. Chem. 2000, 72, 2275-2287. 
(12) Huddleston, J. G.; Visser, A. F.; Reichert, W. M.; Willauer, H. D.; Broker, G. A.; Rogers, R. D. Characterization and comparision of hydrophilic and hydrophobic room temperature ionic liquids incorporating the imidazolium cation. Green Chem. 2001, 3, 156-164.

(13) Dymond, J. H.; Malhotra, R. The Tait equation: 100 years on. Int. J. Thermophys. 1988, 9, 941-951.

(14) Saul, A.; Wagner, W. New international skeleton tables for the thermodynamic properties of ordinary water substance. J. Phys. Chem. Ref. Data 1988, 17, 1439-1462.

(15) NIST Chemistry WebBook. http://webbook.nist.gov/chemistry/.

(16) Piñeiro, M. M.; Bessières, D.; Gacio, J. M.; Saint-Guirons, H.; Legido, J. L. Determination of high-pressure liquid density for $n$-perfluorohexane and n-perfluorononane. Fluid Phase Equilib. 2004, 220, 127136.

(17) Niesen, V. G. (Vapor + liquid) equilibria and coexisting densities of (carbon dioxide $+n$-butane) at 311 to $395 \mathrm{~K}$. J. Chem. Thermodyn. 1990, 22, 777-795

(18) Holcomb C. D.; Outcalt S. L. A Theoretical-based calibration and evaluation procedure for vibrating-tube densimeters. Fluid Phase Equilib. 1998, 150-151, 815-827.

(19) Fandiño, O.; Pensado, A. S.; Lugo, L.; Comuñas, M. P. J.; Fernández, J. Compressed liquid densities of squalane and pentarythritol tetra(2ethylhexanoate). J. Chem. Eng. Data 2005, 50, 939-946.

(20) Fandiño, O.; Garcia, J.; Comuñas, M. P. J.; López, E. R.; Fernández, J. $P \rho T$ measurements and equation of state $(\mathrm{EoS})$ predictions of ester lubricants up to $45 \mathrm{MPa}$. Ind. Eng. Chem. Res. 2006, 45, 1172-1182.

(21) Okoturo, O. O.; VanderNoot, T. J. Temperature dependence of viscosity for room temperature ionic liquids. J. Electroanal. Chem. 2004, 568, 167-181.

(22) Azevedo, R. G.; Esperança, J. M. S. S.; Najdanovic-Visak, V.; Visak, Z. P.; Guedes, H. J. R.; Nunes da Ponte, M.; Rebelo, L. P. N. Thermophysical and thermodynamic properties of 1-butyl-3-methylimidazolium tetrafluoroborate and 1-butyl-3-methylimidazolium hexafluorophosphate over an extended pressure range. J. Chem. Eng. Data 2005, 50, 997-1008.

(23) Zhou, Q.; Wang, L.; Chen, H. Densities and viscosities of 1-butyl3-methylimidazolium tetrafluoroborate $+\mathrm{H}_{2} \mathrm{O}$ binary mixtures from (303.15 to 353.15) K. J. Chem. Eng. Data 2006, 51, 905-908.

(24) Gu, Z.; Brennecke, J. F. Volume expansivities and isothermal compressibilities of imidazolium and pyridinium-based ionic liquids. J. Chem. Eng. Data 2002, 47, 339-345.
(25) Harris, K. R.; Kanakubo, M.; Woolf, L. A. Temperature and pressure dependence of the viscosity of the ionic liquids 1-methyl-3-octylimidazolium hexafluorophosphate and 1-methyl-3-octylimidazolium tetrafluoroborate. J. Chem. Eng. Data 2006, 51, 1161-1167.

(26) Pereiro, A. B.; Tojo, E.; Rodríguez, A.; Canosa, J.; Tojo, J. Properties of ionic liquid $\mathrm{HMIMPF}_{6}$ with carbonates, ketones and alkyl acetates. J. Chem. Thermodyn. 2006, 38, 651-661.

(27) Dzyuba, S. V.; Bartsch, R. A. Influence of structural variations in 1-alkyl(aralkyl)-3-methylimidazolium hexafluorophosphates and bis(trifluoromethylsulfonyl)imides on physical properties of the ionic liquids. Chem. Phys. Chem. 2002, 3, 161-166.

(28) Azevedo, R. G.; Esperança, J. M. S. S.; Szydlowski, J.; Visak, Z. P.; Pires, P. F.; Guedes, H. J. R.; Rebelo, L. P. N. Thermophysical and thermodynamic properties of ionic liquids over an extended pressure range: $[\mathrm{bmim}]\left[\mathrm{NTf}_{2}\right]$ and $[\mathrm{hmim}]\left[\mathrm{NTf}_{2}\right]$. J. Chem. Thermodyn. 2005 $37,888-899$.

(29) Esperança, J. M. S. S.; Guedes, H. J. R.; Blesic, M.; Rebelo, L. P. N. Densities and derived thermodynamic properties of ionic liquids. 3 Phosphonium-based ionic liquids over an extended pressure range. $J$. Chem. Eng. Data 2006, 51, 237-242.

(30) Gómez, E.; González, B.; Domínguez, A.; Tojo, E.; Tojo, J. Dynamic viscosities of a series of 1-alkylimidazolium chloride ionic liquids and their binary mixtures with water at several temperatures. J. Chem. Eng. Data 2006, 51, 696-701.

(31) Diedrichs, A.; Gmehling, J. Measurements of heat capacities of ionic liquids by differential scanning calorimetry. Fluid Phase Equilib. 2006, $244,68-77$.

Received for review June 2, 2006. Accepted September 25, 2006. This work was supported by Fundação para a Ciência e a Tecnologia (Project POCI/EQU/58152/2004). R.L.G. and M.G.F. acknowledge the financial support from Fundação para a Ciência e a Tecnologia through, respectively, their postdoctoral (SFRH/BPD/23246/2005) and Ph.D. (SFRH/BD/14134/2003) scholarships.

JE060247X 